\title{
Regulating emotions at work: The role of emotional intelligence in the process of conflict, job crafting and performance
}

\begin{tabular}{|c|c|}
\hline \multicolumn{2}{|c|}{$\begin{array}{l}\text { Authors: } \\
\text { Monique Sloan }{ }^{1} \text { (D) } \\
\text { Madelyn Geldenhuys }{ }^{1,2} \text { (D) }\end{array}$} \\
\hline \multicolumn{2}{|c|}{$\begin{array}{l}\text { Affiliations: } \\
\text { }{ }^{1} \text { Department of Industrial } \\
\text { Psychology and People } \\
\text { Management, College of } \\
\text { Business and Economics, } \\
\text { University of Johannesburg, } \\
\text { Johannesburg, South Africa }\end{array}$} \\
\hline \multicolumn{2}{|c|}{$\begin{array}{l}{ }^{2} \text { Discipline of Psychological } \\
\text { Sciences, Australian College } \\
\text { of Applied Psychology, } \\
\text { Sydney, Australia }\end{array}$} \\
\hline \multicolumn{2}{|c|}{$\begin{array}{l}\text { Corresponding author: } \\
\text { Madelyn Geldenhuys, } \\
\text { madelyn.geldenhuys@ } \\
\text { outlook.com }\end{array}$} \\
\hline \multicolumn{2}{|c|}{$\begin{array}{l}\text { Dates: } \\
\text { Received: } 21 \text { Jan. } 2021 \\
\text { Accepted: } 05 \text { Mar. } 2021 \\
\text { Published: } 14 \text { June } 2021\end{array}$} \\
\hline \multicolumn{2}{|c|}{$\begin{array}{l}\text { How to cite this article: } \\
\text { Sloan, M., \& Geldenhuys, M. } \\
\text { (2021). Regulating emotions } \\
\text { at work: The role of emotional } \\
\text { intelligence in the process of } \\
\text { conflict, job crafting and } \\
\text { performance. SA Journal of } \\
\text { Industrial Psychology/SA } \\
\text { Tydskrif vir Bedryfsielkunde, } \\
\text { 47(0), a1875. https://doi. } \\
\text { org/10.4102/sajip.v47i0.1875 }\end{array}$} \\
\hline \multicolumn{2}{|c|}{$\begin{array}{l}\text { Copyright: } \\
\text { (C) 2021. The Authors. } \\
\text { Licensee: AOSIS. This wor } \\
\text { is licensed under the } \\
\text { Creative Commons } \\
\text { Attribution License. }\end{array}$} \\
\hline \multicolumn{2}{|l|}{ Read online: } \\
\hline 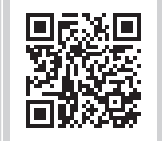 & $\begin{array}{l}\text { Scan this QR } \\
\text { code with your } \\
\text { smart phone or } \\
\text { mobile device } \\
\text { to read online. }\end{array}$ \\
\hline
\end{tabular}

Orientation: This study aimed to investigate the role of emotional intelligence (EQ) in the process of workplace conflict, job crafting and job performance.

Research purpose: To explore the relationship between self-focused EQ, task conflict, task crafting and in-role performance, as well as the relationship between other-focused EQ, relational conflict, relational crafting and extra-role performance.

Motivation for the study: Peer relationships and conflict may have an impact on work performance and enabling employees to manage relationships and conflict at work and may contribute to better overall productivity.

Research approach/design and method: A quantitative research design with cross-sectional analysis utilising PROCESS moderated mediation was followed in this study. The sample consisted of 293 employees across various industries in South Africa.

Main findings: The results showed that task crafting mediates the relationship between task conflict and in-role performance, whilst self-focused EQ moderated the relationship between task conflict, task crafting and in-role performance in the second stage. Relational crafting further mediated the relationship between task conflict and extra-role performance.

Practical/managerial implications: The study shows that job crafting is important for managing conflict on performance, whilst recognising self-focused EQ as an important predisposition to initiate self-driven behaviour that employees embark on in order to perform well.

Contribution/value-add: By analysing these relationships, organisations may better equip their employees with the internal resources needed to perform. Furthermore, an investigation into emotion regulation methods combined with proactive workplace behaviours increases our understanding of how to support and promote positive interactions and proactivity at work.

Keywords: self-focused emotional intelligence; other-focused emotional intelligence; task and relational conflict; task crafting; relational crafting; in-role performance; extra-role performance.

\section{Introduction}

Workplace conflict relates negatively to performance and can induce stress and inhibit employees' ability to be flexible and creative (see De Dreu \& Weingart, 2003). Organisations require proactive and high-performing employees in order to thrive (Jackson, 2014), whilst also requiring employees who can effectively deal with workplace conflict, manage work tasks, manage relationships at work and regulate their emotional responses at work. Furthermore, organisations are unable to fully micro-manage employee relations (Augustine, Payne, Sencindiver, \& Woodcock, 2005), but it is important for organisations and employees to identify the underlying factors (e.g. building rapport amongst colleagues or allowing flexibility in altering a task procedure) that could assist employees in managing performance, relationships and conflict on their own at work for them to function optimally.

Previous research suggests that employees should also take responsibility for their own well-being (Tims, Bakker, \& Derks, 2015) and this becomes especially important during conflict (Boyd, 2007). As a proactive workplace behaviour, job crafting can be useful in promoting 
overall workplace well-being and performance (Petrou, Demerouti, Peeters, Schaufeli, \& Hetland, 2012), whilst also allowing them to have control of job tasks and relationships. If employees can change the task and relational boundaries of their work (e.g. job crafting) and have opportunities for advocacy and inquiry, they will likely be more engaged in and perform better at work (Bakker \& Bal, 2010; Bakker, Tims, \& Derks, 2012; Hakanen, Perhoniemi, \& ToppinenTanner, 2008).

O'Boyle, Humphrey, Pollack, Hawyer and Story (2011) found that having control over one's emotions can help employees overcome stress. Having control over one's emotions and also having a sense of mastery over particularly difficult relationships (e.g. managing conflict) and tasks could therefore benefit employees because they are more capable of managing stress at work. We therefore argue that the ability to change work boundaries will enable employees to deal with conflict and perform well when they are able to appropriately regulate their emotions throughout this process. It is known that individuals who display greater levels of emotional intelligence (EQ) are better equipped to handle conflict at work (Morrison, 2008), whilst also being more able to exhibit self-control, effective communication skills and self-awareness (Yukl, 2002). Possessing these attributes enhances individuals' ability to respond appropriately during conflict (Erkutlu \& Chafra, 2012) and supports productivity and subsequent performance.

This study aims to investigate the impact of employees' EQ on their use of job crafting as a means of dealing with conflict in order to perform effectively. Firstly, this study contributes by showing the relationship between self- and other-focused EQ respectively (Pekaar, Bakker, Born, \& Van der Linden, 2018a) and the process of workplace conflict, job crafting and performance. Secondly, the study examines the effect of job crafting on performance and whether a certain level of EQ may strengthen the positive effects of job crafting on employee performance. This study specifically contributes by showing how self-focused EQ moderates the relationship between task conflict, task crafting and in-role performance and how other-focused EQ moderates the relationship between relational conflict, relational crafting and extrarole performance.

\section{Theoretical framework}

Karasek (1979) developed the job demands-control (JDC) model that explains the relationship between job demands and job controls in understanding employee strain. Job demands include aspects of the job which exert both physical and psychological pressure on the employee, such as working hours, task difficulty and emotional labour (Theorell, Karasek, \& Eneroth, 1990), whilst job control is the autonomy that employees have to regulate and organise their work. De Bruin and Taylor (2006) defined control as an employee's level of autonomy in overall workplace decision-making.
The JDC model is underpinned by the notion that work is composed of different demands and accompanying levels of control, which affect how employees experience their work (Karasek, 1979). This, for example, would mean that low levels of job control and high levels of job demands result in the negative effect of high job strain. However, jobs with both high demand and high control result in employee well-being, as these employees are more active in their roles (Salanova, Peiró, \& Schaufeli, 2002). This produces active jobs where employees learn how to develop new behaviours (see Petrou et al., 2012) - thus having control (e.g. through job crafting) over job demands (e.g. difficult relationships and conflict) can create opportunities for employees to develop new or improved ways of responding to others at work and consequently managing stress.

Conflict is defined as a disagreement between two parties, resulting from discordancy in views on tasks, processes, values and personal areas (Combrink, 2014). Hahn (2000) modelled conflict as one of the greatest stressors that an employee can face in the workplace. As a job demand, workplace conflict is perceived as threatening to an employee's competence (De Bruin \& Taylor, 2006; Rispens \& Demerouti, 2016). This, in turn, creates a situation to which an employee must find a solution, thus further enforcing the notion that conflict is a demand placed on an employee. Skills discretion and decision-making authority form part of the factors of job control (Spreitzer \& Sonenshein, 2003; Theorell \& Karasek, 1996).

These job-control factors focus on employees' discretion to manage and make their own decisions regarding their work. Warren (2003) found that job crafting requires discretion, whereby employees conduct themselves in an autonomous manner. Based on this, employees may gain control in the workplace through job crafting. In this proactive process (Grant \& Ashford, 2008), job crafting allows employees to alter the way in which they use their competencies, expertise and preferences in constructing their overall work experience (Wrzesniewski \& Dutton, 2001). Job crafting is seen as a reflexive role behaviour (Ghitulescu, 2007) and therefore it implies that employees craft their own role, free from rewards or the opinions of others. The job crafting theory posits that employees might alter their work boundaries based on what motivates them and to satisfy basic needs to have control and to connect with others (Wrzesniewski \& Dutton, 2001).

Ghitulescu (2007) found that, when employees face difficulty at work, they took to crafting behaviours as a means to overcome the difficulty. Wall, Jackson, Mullarkey and Parker (1996) stated that employees with the means to control their work-environment stressors are better equipped to deal with their work demands. As job crafting is a self-initiated action, employees may take up crafting to realign themselves to their role (Ghitulescu, 2007) and regain control of their situation. Karasek (1979) understood jobs to be made up of job demands and job controls, and by conceptualising their relationship, also related to increased performance. 
Workplace conflict as a job demand is unavoidable and, by exerting control over one's work through changing the task and relational boundaries at work, allows employees to better deal with conflict demands at work. Both task and relational crafting offer employees a way to make their work meaningful and aligned with their identity (Berg, Grant, \& Johnson, 2010).

\section{The job task: Task conflict, task crafting and in-role performance}

Although an acceptable level of conflict may increase the overall performance outcomes (Schulz-Hardt, Jochims, \& Frey, 2002), high levels of conflict cause employees to feel overwhelmed and they are unable to direct their thoughts appropriately (De Dreu \& Weingart, 2003). Different types of conflict yield different outcomes (Greer, Jehn, \& Mannix, 2008); in the present study, two broad categories of conflict are discussed, namely, task and relational conflict.

Task conflict evolves from disagreements on work goals, tasks, processes and policies (De Dreu \& Weingart, 2003; Desivilya, Somech, \& Lidgoster, 2010). Yang and Mossholder (2004) stated that task conflict is likely to occur when employees disagree on how to approach a task, as each employee may interpret information differently. If not handled well, conflict may supersede the task that the employee or group is required to complete. Although task conflict is perceived as a negative experience by employees (Rispens \& Demerouti, 2016), it allows employees to organise their thoughts constructively (Simons \& Peterson, 2000) and increase their task performance (Hansen, 2015). Thus, task conflict stimulates employees to make reasonable decisions regarding the task disagreement or problem (Lukasik, 2009), which could possibly be promoted with the correct amount of control over their work. Employees craft their jobs because they wish to do things differently, thereby benefiting the organisation's innovativeness (Frese \& Fay, 2001). Employees who shape their work experience through job crafting have shown increases in their overall job satisfaction (Slemp \& Vella-Brodrick, 2013) and job performance (Thompson, 2005). This may be because of an employee feeling a stronger fit with his or her workplace environment when crafting (Tims \& Bakker, 2010).

Wrzesniewski and Dutton (2001) identified task and relational crafting techniques that employees can adopt to redefine their jobs. Task crafting involves the changing of tasks by adding tasks, emphasising certain tasks over others or redesigning current tasks (Berg, Dutton, \& Wrzesniewski, 2013; Nielsen \& Abildgaard, 2012). For example, an employee may volunteer to compile the company performance results into a PowerPoint presentation for a public company presentation because he or she enjoys being creative. In-role performance includes all employees' job duties that are essential to the organisation's functioning (Devonish \& Greenidge, 2010). These job duties form part of the employees' formal job description and include a set of expected behaviours and responsibilities (Sparrowe, Liden, Wayne, \& Kraimer, 2001). In-role performance is usually measured by means of the quality and quantity of output an employee produces within his or her job role and is therefore also referred to as task performance (Kahya, 2007).

H1: Task crafting mediates ${ }^{1}$ the relationship between task conflict and in-role performance.

\section{Relationships at work: Relational conflict, relational crafting and extra-role performance}

Relational conflict occurs when employees have personality clashes or differences in values and beliefs (Desivilya et al., 2010). Relational conflict does not arise from disagreements surrounding tasks, but rather from personal differences or opinions amongst colleagues (Jehn \& Chapman, 2000). This conflict evokes a more emotional and interpersonal situation, which detracts from performance (Jehn \& Chapman, 2000). During relational conflict, employees may have to be accommodating in their reaction and choose to focus on nurturing the relationship (Boyd, 2007). Madlock and BoothButterfield (2012) found that $88 \%$ of employees engage in strategies to adapt their relationships at work in order to manage conflict. Waldman (1994) confirmed this by saying that during times of uncertainty and difficulty (e.g. conflict), employees take up extra roles that are needed for the organisation's survival. Employees need to be able to manage conflict in the workplace in order to perform. The present study proposes that job crafting may be an independent action that an employee can adopt to overcome conflict.

Relational crafting occurs when employees manage their interactions at work by building, reframing or adapting their work relationships, for example, an employee showing an interest in fellow colleagues by getting to know them or finding commonalities in interests. Furthermore, Myers and Johnson (2004) stressed the importance of peer relationships at work, as these increase productivity. Relational crafting serves as a means of changing the social context of employees' work environment (Bakker \& Demerouti, 2007). Employees who choose to interact with colleagues beyond the scope of their role view their work as a means to contribute to the life of their colleagues (Ghitulescu, 2007). However, less relational crafting is required when individuals perceive a work environment to be a safe psychological space where they can freely express themselves (Ghitulescu, 2007).

Extra-role performance constitutes employees' actions that do not form part of their formal job description (Goodman \& Svyantek, 1999) and therefore does not contribute to employees' productivity (Podsakoff, MacKenzie, Paine, \& Bachrach, 2000). Extra-role performance involves acts such as helping employees or assisting new employees (Williams \& Andersen, 1991) and is considered a prosocial behaviour (Dunfield, 2014), spurred on by employees' emotions (Bindle \& Parker, 2010). These actions play a role in forming the organisational and social context in which employees work (Werner, 2000).

1.The term mediation is used in this article in the general sense that explains a model where the values of $Y$ indirectly affects $X$ through $M$. 
H2: Relational crafting mediates the relationship between relational conflict and extra-role performance.

\section{Emotional intelligence}

Emotional intelligence can also be viewed as a way in which an individual may approach an emotion-evoking situation that is intrapersonal or interpersonal in nature (Petrides \& Furnham, 2003). An individual that displays EQ is self-aware and, through this self-awareness, may better identify his or her own emotions, as well as the emotions that others might feel (Petrides \& Furnham, 2003; Schutte et al., 2001). Emotional intelligence can be classified into self- and otherfocused EQ. Self-focused EQ refers to dealing with one's own emotions, and other-focused intelligence refers to dealing with the emotions of others (Pekaar, Bakker, Van der Linden, \& Born, 2018b). Emotional intelligence is conceptualised according to two broad dimensions: emotional appraisal and emotional regulation (Salovey \& Mayer, 1990).

Emotional appraisal involves the identification of the emotion and acknowledgement, and thereafter emotional regulation occurs, where individuals adjust their emotions to suit the situation. When exploring self- and other-focused EQ, different life areas may be impacted (Pekaar et al., 2018b). Self-focused EQ is more likely to impact individuals in their personal capacity, whereas other-focused EQ plays a greater role when people interact. Therefore, in order to yield comprehensive results, EQ was explored from a self- and other-focused perspective in this study.

\section{The role of emotional intelligence in the process of workplace conflict, job crafting and performance}

Collaboration amongst employees is conducive to enhance employee performance (Prati, Douglas, Ferris, Ammeter, \& Buckley, 2003), should their interactions allow for individual empowerment and flexibility (Erkutlu \& Chafra, 2012). Van Rooy and Viswesvaran (2004) defined EQ as:

[T] he set of abilities (verbal and nonverbal) that enable a person to generate, recognise, express, understand and evaluate their own and others, emotions in order to guide thinking and action that successfully cope with environmental demands and pressures. (p. 72)

A study by Caruso and Salovey (2004) found a positive relationship between employee EQ and the ability to work effectively in a team. Employees with higher levels of EQ display adaptability to stressful social encounters such as conflict (Lopes, Grewal, Kadis, Gall, \& Salovey, 2006). Research aimed at understanding the consequences of job crafting has shown that this may increase conflict, as employees may be apprehensive about the changes that job crafting brings to the job role and workplace (Tims et al., 2015).

This indicates the need to investigate under which EQ conditions employees use job crafting to navigate conflict situations in constructive ways, in order to perform. Moreover, the act of job crafting has been found to alter the meaning and subsequent purpose of an employees' job role (Wrzesniewski \& Dutton, 2001), implying that both in-role and extra-role performance may be impacted by selective and purposeful way in which employees craft their work. Organisational performance has also been shown to increase when employees are given opportunities to engage in roles outside of their formal requirements (Worline, Wrzesniewski, \& Rafaeli, 2002). The relationships between conflict, job crafting, EQ and performance are largely unknown.

\section{Self-focused emotional intelligence, task conflict, task crafting and in-role performance}

As EQ has been found to be correlated with self-monitoringtype behaviours (Schutte et al., 2001), it can be expected that possessing self-focused EQ may contribute to experiences that require individuals to act independently (e.g. task crafting and in-role performance). Individuals with high selffocused EQ understand what they are feeling and through this understanding they are more readily able to find solutions to their problems (Matthews, Roberts, \& Zeidner, 2004). Therefore, in the present study, we expected employees with higher levels of self-focused EQ to focus more on task crafting when faced with task conflict in order to enhance their in-role performance.

The relationship between EQ and job crafting has not yet been explored in the existing literature. As mentioned before, employees who can self-regulate are more task-focused and perform better in their job (Bakker \& Bal, 2010). A work environment is conducive to the act of crafting when employees feel the freedom to proffer new ideas and ways of doing things (Gilson \& Shalley, 2004). However, when conflict is experienced, employees may not feel the autonomy they need to craft; this may then encourage the inclusion of EQ as a means of re-establishing an engaging environment. Tsai, Chen and Liu (2007) indicated that positive moods, through motivational and interpersonal processes, predict task performance. This alludes to the notion that stabilised emotions may positively affect employees' ability to adapt their behaviour (task crafting) in order to perform.

Thus, the following hypothesis is formulated (see Figure 1).

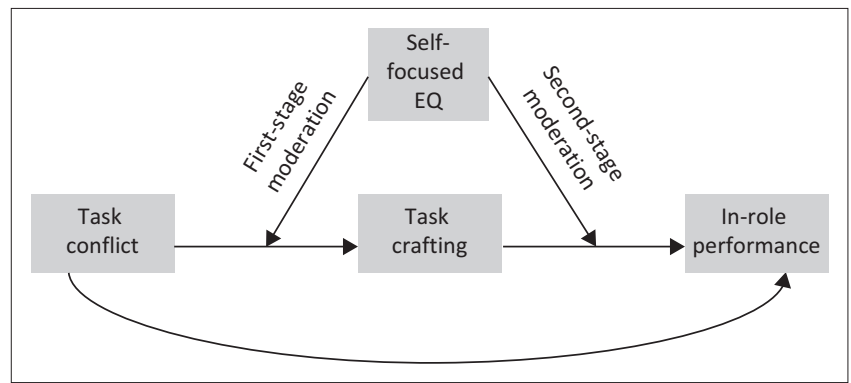

Note: Independent variable $=$ Task conflict; Mediator = Task crafting; Dependent variable $=$ In-role performance; Moderator $=$ Self-focused $E Q$.

$E Q$, emotional intelligence.

FIGURE 1: Conceptual model 1. 
H3: Self-focused EQ moderates the relationship between task conflict, task crafting and in-role performance.

\section{Other-focused emotional intelligence, relational conflict, relational crafting and extra-role performance}

As previously mentioned, the conditions under which employees rely on specific focused EQ are unclear - more specifically, the role of other-focused EQ and how it moderates the relationship between relational conflict, relational crafting and performance could help us to understand relationships at work. A study by Rispens and Demerouti (2016) found that the emotional arousal as a result of conflict is unpredictable. Because of this, EQ may be beneficial as it makes employees capable of understanding and regulating whatever emotions workplace conflict evokes. Emotionally intelligent employees have been found to desire positive outcomes for both themselves and their colleagues (Schutte et al., 2001); this may support the fact that EQ contributes to both in-role and extra-role performance.

Promís (2008) suggested that employees with a low level of EQ may not be able to perform adequately at work as they may lack the flexibility and agility required in times of adversity. It is not always easy to deal with the emotions of others and, as a result, this inability could negatively impact how employees perform. Performance is not only task based but also socially based. Pekaar et al. (2020) pointed out that focusing on appraising and regulating the emotions of others can contribute to performance because it influences social and performance outcomes. Employees can effectively understand the emotions of others (see Pekaar et al. 2020) and tactfully use relational crafting at work to improve social relationships - this in turn could be beneficial in dealing with conflict to optimise extra-role performance. Firstly, we expect higher levels of other-focused EQ to influence an employee's use of relational crafting in order to ameliorate the effects of relational conflict because employees with other-focused EQ better understand their colleagues' emotions; thus, when experiencing conflict, these employees may choose to focus on regulating the relationship as a means of restoring accord. In addition, we looked to associate this predicted relationship with extrarole performance as employees require understanding of one another to perform uniformly (Welbourne, Johnson, \& Erez, 1998). Extra-role performance happens when employees assist others in finishing tasks to reach the overall organisational goals:

H4: Other-focused EQ moderates the relationship between relational conflict, relational crafting and extra-role performance.

\section{Method \\ Procedure and sample}

Respondents in this study were sent an online URL link that allowed them access to a Google survey comprising four questionnaires. Prior to completing the questionnaires, respondents were asked to read an informative document that briefly explained the research study and the purpose of collecting the data. This document further stressed the criteria that respondents had to meet in order to be eligible for participation, which was a voluntary process, and the ethical considerations of this study. Lastly, the researcher's details were provided, should the respondents have any further questions regarding the study. Once the respondents had given their informed consent to participate, the online survey was made available to them for completion. The online survey was password-protected, thereby ensuring that all the recorded data were secure. All the data responses were downloaded from the secure online platform and safely stored. The following criteria were considered to be suitable for the study: one should have at least 1 year's work experience, a grade-12 qualification (to show their proficiency in English), age 18 years or older, and lastly one should be currently working in an organisation. A non-probability convenience sampling strategy was implemented, which yielded an initial sample of 295 respondents from the South African workforce. From the online questionnaires, the data from a final sample of $n=293$ could be processed and analysed.

The sample consisted of 79 men (23\%) and 214 women (73\%). Respondents were predominantly aged 19-39 years (61.7\%), and the majority of the respondents were white people (87.4\%). Of the respondents, almost two-thirds (64\%) indicated English as their home language and 24\% stipulated Afrikaans. A total of $79.9 \%$ had a bachelor's degree or higher qualification. Although the majority were white, female and English, the respondents showed to be from various job positions: junior mangers (16.4\%), middle managers (20.8\%), senior managers (15\%) and non-managers (23.2\%).

\section{Measures}

A biographical questionnaire was used to evaluate the sample with regard to their demographic composition. Respondents were required to indicate their age, gender, ethnicity and home language.

The intragroup conflict scale (ICS) was adapted to measure conflict (Jehn, 1995). This scale consists of nine items, measured on a five-point Likert scale ranging from 1 (none) to 5 (a great deal). Conflict was measured using two subscales: relational conflict, comprising five items (e.g. 'there were tendencies of anger and aggression between some persons in the group') and task conflict, comprising four items (e.g. 'during conflict, the group was concerned about solving problems by using a sensible and rational procedure'). Jehn and Mannix (2001) reported a Cronbach's alpha of 0.94 for both relational conflict and task conflict. This study found reliabilities of 0.82 for task conflict and 0.84 for relational conflict $\alpha=0.84$.

The job crafting questionnaire (JCQ) was used to measure the extent to which individuals engage in job-crafting activities (Slemp et al., 2013). Two types of job crafting were identified: task crafting and relational crafting. The JCQ 
comprises 15 items that are rated on a six-point Likert scale ranging from 1 (hardly ever) to 6 (very often). Examples of the items for the two job-crafting activities are as follows: (task crafting) 'change the scope or type of tasks that you complete at work' and (relational crafting) 'make friends with people at work who have similar skills or interests'. The JCQ has been validated by Slemp, Kern and Vella-Brodrick (2015) and was found to have an acceptable Cronbach's alpha (overall: $\alpha=0.91$; task crafting: five items, $\alpha=0.86$; relational crafting: five items, $\alpha=0.84$ ). Task crafting reported a Cronbach's alpha of 0.76 and relational crafting reported a Cronbach's alpha of 0.76 .

The Rotterdam Emotional Intelligence Scale (REIS) (Pekaar et al., 2018a) was used to measure EQ in the present study. The scale further distinguishes four factors, namely, selfand other-focused emotional regulation and self- and otherfocused emotional appraisal. It comprises 28 items, which respondents are required to answer using a five-point Likert scale ranging from 1 (totally disagree) to 5 (totally agree). Examples of the items that were divided into the four-factor structure are the following: (self-focused emotional appraisal) 'I can distinguish my own emotions well', (otherfocused emotional appraisal) 'I understand why others feel the way they feel', (self-focused emotional regulation) 'I am in control of my own emotions' and (other-focused emotional regulation) 'I have great influence over how others feel'. In the development and validation of the REIS, Pekaar et al. (2018a) found Cronbach's alpha coefficients in the range of 0.82 to 0.85 for the four subscales and an overall scale coefficient of 0.88 . Self-focused EQ had a reliability of $\alpha=0.89$ and other-focused EQ had a reliability of $\alpha=0.92$.

Performance was measured using items adapted from Goodman and Svyantek's (1999) Performance Scale. Using six items, two roles types were measured: in-role performance (e.g. 'I met all the requirements of my position') and extra-role performance (e.g. 'I helped colleagues who were under high work pressure or who had other problems'). The respondents answered using a seven-point Likert-type scale ranging from 0 (totally disagree) to 6 (totally agree). Jackson (2014) found the scale to have a Cronbach's alpha coefficient of 0.88 . The Cronbach's alpha coefficient for extra-role performance was 0.82 and for in-role performance it was 0.87 .

\section{Statistical analysis}

A statistical analysis was carried out using the Statistical Package for Social Sciences (SPSS) statistical program 25 (SPSS Inc., 2018), utilising Version 3.2 of Hayes PROCESS (Hayes, 2013). In order to calculate the direct and indirect effects of this simple mediation, Model 4 in the PROCESS macro of Hayes (2013) was used. In Model 4, the path labelled $c^{\prime}$ represents the direct effect of $X$ on $Y, c$ is the total effect of $X$ on $Y$, and the product of the paths labelled $a$ and $b$ represents the indirect effect of $X$ on $Y$, which determines how much the $c$ path is changed when $\mathrm{M}$ (the mediator) is added to the model (Bollen, 1989;
Hayes, 2013). Thus, the mediator will add to the model's variance and explain why the independent and dependent variables may be related. Bootstrapping, utilising 5000 bootstrap samples, was used to calculate the $95 \%$ confidence interval (CI), which aids in understanding the effect size $\left(c-c^{\prime}\right)$.

First- and second-stage moderated mediation (conditional indirect effect) tests were conducted, whereby the mediating process was moderated, because $W$ alters the relationship between X, M and Y (Preacher, Rucker, \& Hayes, 2007). The study aimed to calculate the conditional indirect of conflict on performance through job crafting at different values of $E Q$. The results consisted of the association between conflict and job crafting ( $a$-path), job crafting and performance (b-path), the direct effect of conflict on performance ( $c^{\prime}$-path), the interaction effect of conflict and $E Q$ on job crafting, and lastly the interaction effect of job crafting and $E Q$ on performance. This conditional indirect effect was tested using PROCESS Model 7 (Hayes, 2013), which tests the first stage of moderated mediation. Similarly, PROCESS Model 14 (Hayes, 2013) was used to test for second-stage moderated mediation. An index of moderated mediation was calculated by generating bootstrapping confidence intervals, whereby no zero indicates a significant conditional indirect effect (Hayes, 2015). Preceding the analyses of Models 7 and 14, both the $\mathrm{X}^{*} \mathrm{M}$ and $\mathrm{M} * \mathrm{~V}$ interaction terms were, respectively, meancentred (Cohen, Cohen, West, \& Aiken, 2003) using the PROCESS V.3.2 add-on package.

\section{Ethical considerations}

The results of this study formed part of a research project undertaken in the fulfilment of a postgraduate degree. Ethical clearance was obtained from the ethics committee at the University of Johannesburg, number IPPM-2018-248 (M). The data were collected between June and August 2018.

\section{Results \\ Descriptive statistics and correlations}

Prior to performing statistical analyses, descriptive statistics were calculated for each of the four scales, together with the reliability of their subscales. Assumptions of normality were met (Pallant, 2011). Pearson's correlation analysis was conducted to determine whether the variables in each of the conceptual models were related. These correlations are presented in Table 1. The variables in Conceptual Model 1 were the following: task conflict, task crafting, self-focused $E Q$ and in-role performance, which demonstrated statistically significant positive correlations $(p<0.001)$. The results showed weak relationships between self-focused $E Q$ and task conflict $(r=0.16)$, between self-focused $E Q$ and task crafting $(r=0.14)$ and between in-role performance and task conflict $(r=0.18)$. Medium effect sizes and correlations were found between task crafting and task conflict $(r=0.25)$, between 
TABLE 1: Pearson's correlations analysis.

\begin{tabular}{lccc}
\hline Variable & $\mathbf{1}$ & $\mathbf{2}$ & $\mathbf{3}$ \\
\hline Conceptual model 1 & & & \\
1. Task conflict & 1 & - & - \\
2. Task crafting & $0.25^{* *}$ & 1 & - \\
3. Self-focused EQ & $0.16^{* *}$ & $0.14^{* *}$ & 1 \\
4. In-role performance & $0.18^{* *}$ & $0.27^{* *}$ & $0.27^{* *}$ \\
Conceptual model 2 & & & \\
1. Relational conflict & 1 & - & - \\
2. Relational crafting & $-0.12^{*}$ & 1 & - \\
3. Other-focused EQ & 0.01 & $0.31^{* *}$ & 1 \\
4. Extra-role performance & 0.02 & $0.36^{* *}$ & $0.32^{* *}$ \\
\hline
\end{tabular}

EQ, emotional intelligence.

*, $p<0.005 ; * *, p<0.001 ; r>0.10$ (small effect); $r>0.30$ (medium effect); $r<0.50$ (large effect).

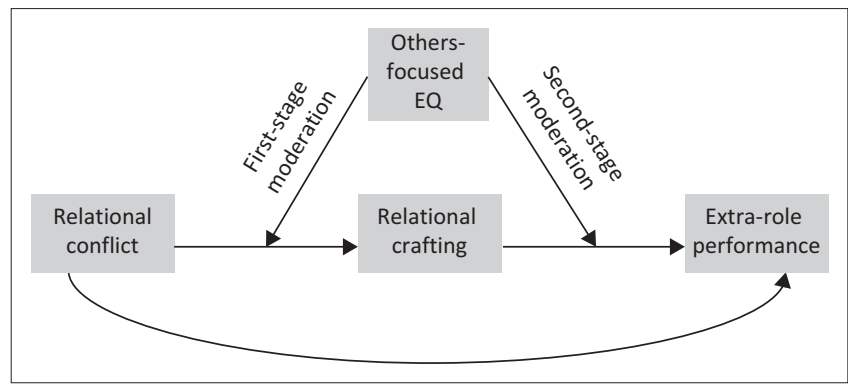

Note: Independent variable = Relational conflict; Mediator = Relational crafting; Dependent variable $=$ Extra-role performance; Moderator $=$ Other-focused $E Q$.

$E Q$, emotional intelligence.

FIGURE 2: Conceptual model 2.

in-role performance and task crafting $(r=0.27)$ and between inrole performance and self-focused EQ $(r=0.27)$.

Variables in Conceptual Model 2 (Figure 2) ( $X=$ relational conflict, $M=$ relational crafting, $Y=$ extra-role performance) showed mixed results. Other-focused EQ and extra-role performance were not significantly related to relational conflict $(p<0.05)$. Relational conflict and relational crafting showed a weak but statistically significant negative correlation $(r=-0.12 ; p<0.05)$. Statistically significant relationships existed between the second-stage moderation variables $(p<0.001)$, with weak to medium effect sizes. More specifically, extra-role performance and relational crafting had a positive but medium relationship $(r=0.36)$, extra-role performance and other-focused $E Q$ showed a positive but medium relationship $(r=0.32)$ and other-focused $E Q$ and relational crafting demonstrated a medium positive relationship $(r=0.31)$.

\section{Simple mediation analysis}

Hypothesis 1 indicated that job crafting mediates the relationship between conflict $(\mathrm{X})$ and job performance $(\mathrm{Y})$. Table 2 shows the results of the mediation analysis of Conceptual Model 1 ( $\mathrm{X}=$ task conflict, $\mathrm{M}=$ task crafting and $\mathrm{Y}=$ in-role performance).

This model indicated that path $a$ of task conflict to task crafting was significant $(\beta=0.3352 ; p=0.000)$. Path $b$ in the model indicated the relationship between task crafting and in-role performance $(\beta=0.137 ; p=0.000)$. The direct effect of task
TABLE 2: Simple mediation model results.

\begin{tabular}{lcccccc}
\hline Variable & $\boldsymbol{\beta}$ & $\mathrm{SE}$ & $\boldsymbol{t}$ & $\boldsymbol{p}$ & $\mathrm{Cl}$ (lower) & $\mathrm{Cl}$ (upper) \\
\hline Conceptual model 1 & & & & & & \\
$X \rightarrow M(a)$ & 0.3352 & 0.0776 & 4.3197 & $0.00^{* *}$ & 0.1824 & 0.4879 \\
$M \rightarrow Y(b)$ & 0.1376 & 0.0340 & 4.0522 & $0.00^{* *}$ & 0.0708 & 0.2045 \\
$X \rightarrow Y(c)$ & 0.1404 & 0.0461 & 3.0484 & $0.002^{*}$ & 0.0498 & 0.2310 \\
$X \rightarrow Y\left(c^{\prime}\right)$ & 0.0943 & 0.0463 & 2.0360 & $0.042^{*}$ & 0.0031 & 0.1854 \\
$X \rightarrow M \rightarrow Y\left(c-c^{\prime}\right)$ & 0.0461 & - & - & - & 0.0170 & 0.0834 \\
Conceptual model 2 & & & & & & \\
$X \rightarrow M(a)$ & -0.1213 & 0.0606 & -2.001 & $0.0464^{*}$ & -0.2407 & -0.0020 \\
$M \rightarrow Y(b)$ & 0.2123 & 0.0316 & 6.713 & $0.000^{* *}$ & 0.1500 & 0.2745 \\
$X \rightarrow Y(c)$ & 0.0115 & 0.0351 & 0.3263 & 0.745 & -0.0576 & 0.0805 \\
$X \rightarrow Y\left(c^{\prime}\right)$ & 0.0372 & 0.0329 & 1.1297 & 0.2596 & -0.0276 & 0.1020 \\
$X \rightarrow M \rightarrow Y\left(c-c^{\prime}\right)$ & -0.0258 & - & - & - & -0.0570 & 0.0025 \\
\hline$X$, relational conflict; $M$, relational crafting; $Y$, extra-role performance; Cl, confidence \\
interval; SE, standard error. & & & & & \\
$*, p<0.005 ; * *, p<0.001$. & & & & &
\end{tabular}

conflict on in-role performance (path $c^{\prime}$ ) was significant and therefore full mediation did not occur $(\beta=0.0943 ; p=0.0427)$. The indirect effect results showed that partial mediation occurred $(95 \% \mathrm{CI}=[0.017 / 0.083])$.

Hypothesis 2 stated that relational crafting mediates the relationship between relational conflict and extra-role performance. Table 2 shows that paths $a$ and $b$ were found to be significant $(p<0.05)$. Path $a$ revealed a negative coefficient $(\beta=-0.1213)$, indicating that the more employees experience relational conflict at work, the less they craft relationally. Path $b$ showed a positive relationship $(\beta=0.2123)$; thus, higher in-role performance is reported when employees engage in relational crafting. However, the direct, total and indirect effects were all found to be non-significant $(p>0.05)$. This implies that relational crafting does not mediate the relationship between relational conflict and extra-role performance.

\section{Moderated mediation analysis}

Moderated mediation analysis was used to calculate the conditional indirect effect of Conceptual Models 1 and 2 singly (see Kraemer, Kiernan, Essex, \& Kupfer, 2008). The indirect effect indicates the effect of conflict $(X)$ on performance $(Y)$ through job crafting $(M)$. The conditional factor constitutes how this specified indirect effect differs at different levels of EQ (W/V). In each conceptual model, first-stage (Model 7) and second stage (Model 14) moderated mediation was tested. In addition, 5000 bootstrap samples were used and 95\% CIs were computed by determining the indirect effects at $-1,0$ and +1 standard deviation (SD).

Hypothesis 3 indicated that the process of task conflict, task crafting and in-role performance was moderated by selffocused EQ. Conceptual Model 1 was defined as follows: $X=$ task conflict, $M=$ task crafting, $\mathrm{W} / \mathrm{V}=$ Self-focused EQ and $Y=$ in-role performance. Table 3 shows that in the first stage, the direct $c^{\prime}$ path remained significant $(\beta=0.0943 ; p=0.0427)$. However, the bootstrapped estimates showed a nonsignificant moderated mediation effect, as zero was present 
within the confidence interval, thus implying that zero was a probable value: $\beta=0.006$; standard error $(\mathrm{SE})=0.0017 ; 95 \%$ CI $(-0.0034 ; 0.0034)$. Thus, in the first stage of the model, self-focused EQ did not alter the extent to which task crafting accounted for the link between task conflict and in-role performance.

Moderated mediation was then tested in the second stage for Conceptual Model 1. The overall model was significant $\left(F_{[4.287]}=12.69 ; p<0.0001 ; R^{2}=0.1503\right)$; however, the direct $c^{\prime}$ path was found to be non-significant $(p=0.0875)$. There was a significant conditional indirect effect of task crafting on in-role performance through self-focused EQ $(\beta=-0.0092 ; p=0.0096)$. The test of moderated mediation was significant: $\beta=-0.0031$; $\mathrm{SE}=0.0015 ; 95 \% \mathrm{CI}(-0.0063 ;-0.0004)$ and zero did not span the CI. This implies that the direct and indirect effects, as well as the conditional indirect effects, were different from one another with the addition of the moderator EQ (Hayes, 2013). Furthermore, the secondstage moderated mediation model accounted for $15.03 \%$ of the variance in in-role performance when task crafting was utilised. Hypothesis 3 is thus accepted in the second stage (see Table 3). Self-focused EQ was found to moderate the relationship between task conflict and in-role performance (through task crafting) in the second stage. The conditional indirect effects are visually presented in Figure 3. Significant conditional indirect effects were found for low $(-1 \mathrm{SD})$ and average (0 SD) values of self-focused EQ. This suggests that individuals who exhibit low to moderate levels of self-focused EQ will have a stronger positive relationship when using task crafting in order to perform their job duties when experiencing task conflict, compared with individuals with high self-focused EQ. Figures 4 and 5 depict the overall direct and indirect effects of the moderated mediation conducted on Conceptual Model 1.

For Conceptual Model 2, a first- and second-stage moderated mediation was conducted using Hayes PROCESS Models 7 and 14, respectively. Hypothesis 4 indicated that otherfocused EQ moderated the process of relational conflict, relational crafting and extra-role performance. Conceptual
Model 2 variables were defined as follows: $X=$ relational conflict, $M=$ relational crafting, $\mathrm{W} / \mathrm{V}=$ other-focused EQ and $Y=$ extra-role performance. Identical bootstrap samples and CI were used. In both the first and second stage of the moderated mediation, the direct effect and interaction terms were non-significant $(p>0.05)$. Although it is suggested that relationships should not be disregarded based on $p$-values (Bangdiwala, 2016), it can still be concluded that moderated mediation did not occur, as zero spanned the CIs of the index of moderated mediation (first stage 95\% CI [-0.0047; $0.0015]$ and second stage $95 \% \mathrm{CI}[-0.0006 ; 0.0011])$. Hypothesis 4 is therefore rejected.

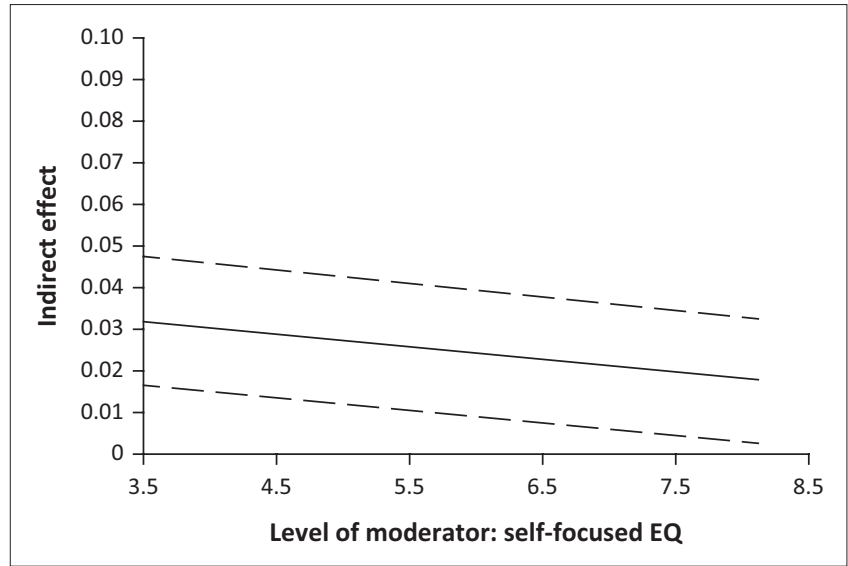

EQ, emotional intelligence.

FIGURE 3: Conditional indirect effects of task conflict on in-role performance through task crafting at values of self-focused emotional intelligence.

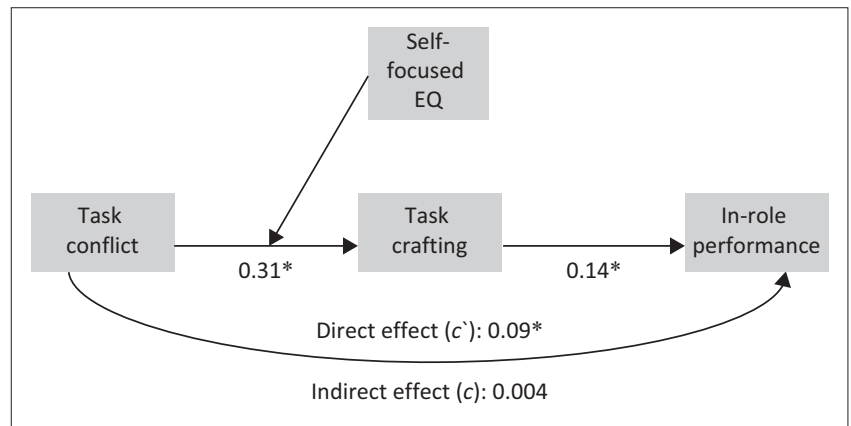

EQ, emotional intelligence.

FIGURE 4: Conceptual model 1 showing first-stage moderated mediation.

TABLE 3: Conceptual model 1: Moderated mediation results.

\begin{tabular}{|c|c|c|c|c|c|c|}
\hline Conceptual model 1 & $\beta$ & SE & $t$ & $p$ & $\mathrm{Cl}$ (lower) & $\mathrm{Cl}$ (upper) \\
\hline \multicolumn{7}{|l|}{ 1st stage } \\
\hline$X \rightarrow M(a)$ & 0.3061 & 0.0800 & 3.8254 & $0.0002 *$ & 0.1486 & 0.4636 \\
\hline$M \rightarrow Y(b)$ & 0.1376 & 0.0340 & 4.0522 & $0.001 *$ & 0.0708 & $0.2045^{*}$ \\
\hline$X \rightarrow Y\left(c^{\prime}\right)$ & 0.093 & 0.0463 & 2.0360 & $0.0427^{*}$ & 0.0031 & 0.1854 \\
\hline$X^{*} W \rightarrow Y$ & 0.004 & 0.0098 & 0.4099 & 0.6822 & -0.0153 & 0.0233 \\
\hline Index of moderated mediation & 0.0006 & 0.0017 & - & - & -0.0034 & 0.0034 \\
\hline \multicolumn{7}{|l|}{ 2nd stage } \\
\hline$X \rightarrow M(a)$ & 0.3352 & 0.0776 & 4.3197 & $0.000 * *$ & 0.1824 & 0.4879 \\
\hline$M \rightarrow Y(b)$ & 0.1274 & 0.0330 & 3.8598 & $0.0001^{*}$ & 0.0624 & 0.1924 \\
\hline$X \rightarrow Y\left(c^{\prime}\right)$ & 0.0776 & 0.0452 & 1.7145 & 0.0875 & -0.0115 & 0.1666 \\
\hline$M^{*} V \rightarrow Y$ & -0.0092 & 0.0035 & -2.6089 & $0.0096 *$ & -0.0161 & -0.0022 \\
\hline Index of moderated mediation & -0.0031 & 0.0015 & - & - & -0.0063 & $-0.0004 *$ \\
\hline
\end{tabular}

$X$, Task conflict; $M$, task crafting; $\mathrm{W} / \mathrm{V}$, self-focused $\mathrm{EQ} ; Y$, in-role performance; $\mathrm{Cl}$, confidence interval; $\mathrm{SE}$, standard error

$*, p<0.005 ; * *, p<0.001$. 


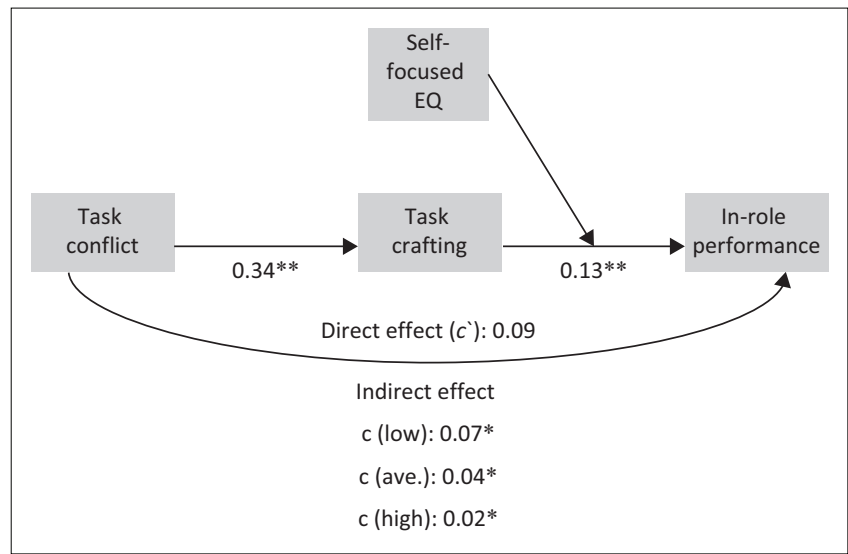

EQ, emotional intelligence; ave., average.

FIGURE 5: Conceptual model 1 showing second-stage moderated mediation.

\section{Discussion}

In this study, two conceptual models were proposed to explore the relationships between four variables. The main aim of Conceptual Model 1 was to explore the relationships between task conflict, task crafting, self-focused EQ and inrole performance. Conceptual Model 2 explored the relationships between relational conflict, relational crafting, other-focused EQ and extra-role performance. This study explored these relationships with no demographical restrictions, but rather looked to understand the general employee experience. More specifically, this study was aimed at uncovering relationships that may exist between variables by calculating the direct, indirect and conditional effects. These effects were calculated by conducting mediation, and moderation and moderated mediation analyses of both Conceptual Models 1 and 2.

\section{Task conflict, task crafting and in-role performance (indirect effect)}

The results showed that task conflict had a direct and positive effect on in-role performance. The results therefore suggest that employees are more effective when their job duties are challenging, or likewise, when they encounter resistance when looking for a solution to a problem. Task conflict involves all task-related challenges or disagreements encountered at work (Desivilya et al., 2010). In-role performance, also referred to as task performance, encompasses the job duties that the employee is required to perform in order for an effective role and organisational functioning (Devonish \& Greenidge, 2010). The findings of Hansen (2015), Lukasik (2009), Pelled, Eisenhardt and Xin (1999) and Wit, Greer and Jehn (2012) supported this study's finding that task conflict increases task performance. Therefore, employees facing task conflict have been shown to make better task-related decisions at work.

In addition, task conflict was found to positively affect task crafting, indicating that individuals are likely to craft their tasks when experiencing task conflict. This finding is supported by research as employees were found to craft their tasks more when they faced challenges in their job tasks (Petrou, Demerouti, \& Schaufeli, 2015) and when their workload increased (Wrzesniewski \& Dutton, 2001). These findings further support the notion that task crafting has a positive affect on an employees' performance of their job tasks. Therefore, Hypothesis 1, stating that task crafting mediates the relationship between task conflict and in-role performance, was accepted. Employees who confront task conflict through task crafting perform better in their specific task roles. This result could be partly explained by the finding that employees who are proactive in dealing with the challenges at work perform better at their tasks (Demerouti, 2014; Tornau \& Frese, 2013). Likewise, Slemp and Vella-Brodrick (2013) found that, when employees craft their tasks, they are better able to satisfy their intrinsic needs (such as the need for autonomy and competence in their work tasks). Contrary to Hypothesis 1, employees who craft as a means to decrease their challenging job demands (e.g. task conflict) may try to reduce their work responsibilities to the detriment of their overall task performance (Tims, Bakker, \& Derks, 2013).

\section{Task conflict, task crafting, self-focused emotional intelligence and in-role performance (conditional indirect effect)}

The results showed that all four variables showed significant positive correlations with one another. The moderated mediation analysis of Conceptual Model 1 yielded a significant result. Self-focused EQ was found to be a significant moderator of the indirect effect of task conflict on in-role performance through task crafting in the second stage (H3a). Specifically, low and average levels of self-focused EQ were stronger moderators of the path between task crafting and in-role performance in the presence of task conflict in the overall model. Therefore, when task conflict is experienced, employees who choose to craft their tasks will perform better when they possess a low to average level of self-focused EQ. Interestingly, these results imply that not being able to regulate one's own emotions (i.e. low levels of self-focused EQ) during times of increased task conflict still results in increased in-role performance when task crafting is performed. Therefore, we can assume that crafting plays a very important role in regulating the effects of conflict on inrole performance, especially if employees are less able to regulate their self-focused $\mathrm{EQ}$. We may also assume that emotions do not affect work behaviours to a great extent. It may also be that the employees in this sample did not place importance on emotions when performing job tasks.

In exploring the result for average levels of self-focused EQ, the ability to both acknowledge and control their emotions, even in a slight way, will enhance employees' ability to craft successfully. A possible reason for this is the enrichment that self-focused EQ offers to employees' overall attitude towards and satisfaction with their job (Brunetto, Teo, Shacklock, \& Farr-Wharton, 2012). This suggests that employees who are able to craft their tasks whilst not overly focused on their emotions will perform better. This may be because the 
employees are able to prioritise the task. Secondary support was found for Fredrickson's (2001) finding that individuals who constructively handle their emotions will adapt their ways (e.g. task crafting), even when they are faced with adverse conditions (e.g. task conflict).

The results of this study serve as further confirmation of the benefits that both task crafting and self-focused EQ could bring to employees' ability to overcome their task difficulties, in order to perform. Furthermore, certain levels of selffocused EQ strengthen these relationships. For example, the results showed that high levels of self-focused EQ do not affect the indirect relationship. Employees with high levels of self-focused EQ possibly already manage their relationships; thus, we can say that task conflict does not affect their performance through task crafting. We may then assume that these employees are better able to put their personal feelings aside when experiencing conflict, for the sake of achieving the task.

\section{Relational conflict, relational crafting and extra- role performance}

It is important to observe that respondents experienced relational conflict to a certain degree and indicated that they frequently engaged in extra-role activities. Relational conflict is the interpersonal problems that exist amongst co-workers (De Dreu \& Weingart, 2003) and therefore is considered to encompass negative emotions. Extra-role performance involves showing care and concern for the well-being of colleagues, of one's own accord (Goodman \& Svyantek, 1999). The relationship between relational conflict and extra-role performance was non-significant and the two variables had close to zero relationship with one another in the correlation and regression analyses. This suggests that when employees are faced with relational conflict, their extra-role performance is not directly affected. This may be because of employees choosing to distance the two experiences, so as not to cause further discord in their workplace relationships (Trougakos, Beal, Green, \& Weiss, 2008). In addition, Schreurs, Van Emmerik, Günter and Germeys (2012) found that extra-role performance was likely to be intrinsically initiated by employees and not contextually reliant. Based on extant literature (De Wit, Greer, \& Jehn, 2012), it was expected that these two variables would have a negative direct relationship.

Despite the fact that the variables did not relate as expected, the model still yielded some significant results. Relational conflict had a direct negative affect on relational crafting, meaning that the more relational conflict is experienced at work, the less employees will craft relationally. Relational job crafting involves employees changing their behaviour, in a positive way, towards their colleagues (Nielsen \& Abildgaard, 2012), for example, making an effort to get to know people at work. In addition, the finding may be attributable to relational crafting requiring a positive interpersonal work dynamic (Gilson \& Shalley, 2004), where employees feel psychologically safe (Caldwell \& O'Reilly, 2003), neither of which is facilitated by relational conflict. Relational crafting was found to have a positive and direct effect on extra-role performance. This corroborated with findings of Niessen, Weseler and Kostova (2016) and Rudolph, Katz, Lavigne and Zacher (2017), who found that employees who consistently go out of their way to connect with others (extra-role performance) craft their work from a social perspective (relational crafting).

Overall, relational crafting did not mediate the relationship between relational conflict and extra-role performance. This was contradictory to the finding of Gardner, Pickett and Brewer (2000) that there is a natural effort made by employees to socially belong and, to do so, they spend time forming connections with their colleagues. Therefore, it was thought that when employees experience relational conflict, they may want to neutralise hostility (through relational crafting) in order to connect once more with their colleagues (extra-role performance). However, this proved not to be true in the present study. A possible reason for this could be, if people are experiencing relational conflict, they may be less likely to socialise with their colleagues. Slemp and Vella-Broderick (2013) further pointed out that relational crafting measures the extent to which employees will go out of their way to relate to and socialise with others.

\section{Relational conflict, relational crafting, other- focused emotional intelligence and extra-role performance}

The present study found that the indirect effect of relational conflict on extra-role performance, through relational crafting, was not moderated by other-focused EQ in either the first or the second stage (H4). In conceptualising the hypothesised relationship between the given variables, the indirect relationship between relational conflict and extrarole performance, through relational crafting, was understood as a change that an employee is required to navigate by making decisions that will benefit others. Hypothesis 4 was not accepted, as there was little empirical evidence to suggest that moderated mediation would occur (as other-focused EQ failed to moderate the relationship between relational conflict and extra-role performance and relational crafting did not mediate the relationship between relational conflict and extra-role performance). This was contrary to previous research that advocated that prosocial behaviours (such as relational crafting and extra-role performance) depend on prosocial traits (such as otherfocused EQ) (Finkelstein, 2011; Schutte et al., 2001). It was also found that the ability to regulate the emotions of others eased dealings with workplace dilemmas (e.g. relational conflict) (Côté et al., 2011). Furthermore, a metaanalytical study found that this relationship was stronger in job roles that required interpersonal contact (Joseph \& Newman, 2010).

A potential explanation for the lack of moderated mediation is that relational conflict did not correlate with other-focused 
EQ and extra-role performance in the first place, thereby suggesting that no relationship exists amongst those variables. This may be explained by Eslami and Arshadi's (2016) finding that competition in the workplace causes employees to withdraw from prosocial behaviours (e.g. extra-role performance), as helping fellow colleagues did not ensure an increase in their own growth and performance. Moreover, jobs require both self- and other-focused EQ (Elfenbein, 2016). Liu, Prati, Perrewe and Ferris (2008) proposed that even when the situation requires one to focus on others in their approach (relational conflict, relational crafting and extra-role performance), a certain level of selffocus may enhance employees' efforts and motivation. This may be explored in future studies.

\section{Limitations and recommendations}

Although this study yielded some significant results, limitations were evident. Firstly, EQ was measured using a self-report instrument, which may have caused some respondents to give socially desirable responses (Brackett, Rivers, Shiffman, Lerner, \& Salovey, 2006). Future research may look to include ratings from supervisors and/or colleagues, especially in research relating to performance, where people may rate their performance higher than what it is (Tims, Bakker, \& Derks, 2012). Furthermore, because of the use of a convenience sampling technique, the sample consisted of predominantly white female respondents and, therefore, the results are not generalisable to the larger population. Future research should focus on including more people from diverse backgrounds. The study followed a cross-sectional design, and future research should focus on obtaining scores on conflict, job crafting and performance over time. Lastly, the sample consisted of employees from a wide array of professions and industries; therefore, the identified relationships may not be applicable to a specific work context.

Self- and other-focused EQ have received little research attention in the South African context. Therefore, the present research may enable researchers to further explore EQ in the South African workforce, together with the role it plays in other relationships and outcomes, for example, exploring whether a combination of self- and other-focused EQ is more likely to positively impact South African employees' ability to navigate workplace conflict in order to perform. Overall, not much is known about self-focused and other-focused EQ (Pekaar et al., 2018a) in the South African context, and thus researchers and companies should focus on these concepts to gain a better understanding.

This study provides situational context to how the constructs under investigation relate to the workplace. For example, it was hypothesised that employees experiencing relational conflict will take up relational crafting in order to increase their extra-role performance and, furthermore, that this relationship would be moderated by other-focused EQ. Although this relationship proved to be non-significant, future research could target industries that require more relational and people-focused work, such as social work or nursing. Brotheridge and Grandey (2002) found that professionals in these occupations are required to adapt their emotions more regularly than non-human-service professionals. Otherfocused EQ may then prove to be of greater influence in professions that involve more relational-type work.

\section{Conclusion}

The findings of this study contribute to the body of knowledge in terms of identifying the significant relationship between task conflict, task crafting and self-focused EQ and the effects these yield in terms of in-role performance. In addition, this study produced non-significant results regarding the relational aspects of conflict and crafting, their interaction with other-focused EQ and whether these relationships affect extra-role performance.

Conflict within organisations is inevitable and employees are expected to manage their own behaviour in order to perform optimally. Through this study, organisations may be enlightened regarding the influence of $E Q$, and therefore be aware of the benefits it could bring, such as increased employee ability to navigate conflict. This study may guide organisations to understand the self-driven behaviours employees embark on, such as task and relational crafting, in order to perform, regardless of the conflict they experience at work. By analysing these relationships, organisations may better equip their employees with the internal resources needed to perform.

This study identified a statistically significant conceptual model that indicates the relationships between task conflict, task crafting, self-focused EQ and in-role performance within the South African context. The study has shown that South African employees frequently experience both task and relational conflict at work. As managers require employees to overcome conflict swiftly and perform their job duties, it would be useful to identify the benefits of task crafting and self-focused EQ to serve such means. More importantly, this study confirms that low and average levels of self-focused EQ aid the strengthening of the positive consequences of task crafting in order to perform. Recruiters and line managers may benefit from this knowledge, as it suggests that EQ may be an important factor to consider when hiring or retaining talent, but that not all levels of EQ are beneficial.

\section{Acknowledgements}

This article arises from a published thesis submitted in partial fulfilment of the requirements for the degree of Master's in Industrial Psychology in the College of Business and Economics at the University of Johannesburg, South Africa, entitled 'The moderating role of emotional intelligence on the process of workplace conflict, job crafting and job performance', under the supervision of Dr Madelyn Geldenhuys, January 2018. Refer: https://ujcontent.uj.ac. za / vital / access / services / Download / uj:33746/ SOURCE1?view=true 


\section{Competing interests}

The authors declare that they have no financial or personal relationships that may have inappropriately influenced them in writing this article.

\section{Authors' contributions}

M.S. and M.G. contributed equally to the writing of the article.

\section{Funding information}

This research received no specific grant from any funding agency in the public, commercial or not-for-profit sectors.

\section{Data availability}

There are no restrictions on the availability of the data and it can be obtained from the corresponding author, M.G., upon request.

\section{Disclaimer}

The views and opinions expressed in this article are those of the authors and do not necessarily reflect the official policy or position of any affiliated agency of the authors.

\section{References}

Augustine, S., Payne, B., Sencindiver, F., \& Woodcock, S. (2005). Agile project management: Steering from the edges. Communications of the ACM, 48(12) 85-89. https://doi.org/10.1145/1101779.1101781

Bakker, A.B., \& Bal, M.P. (2010). Weekly work engagement and performance: A study among starting teachers. Journal of Occupational and Organizational Psychology, 83(1), 189-206. https://doi.org/10.1348/096317909X402596

Bakker, A.B., \& Demerouti, E. (2007). The job demands-resources model: State of the art. Journal of Managerial Psychology, 22(3), 309-328. https://doi. org/10.1108/02683940710733115

Bakker, A.B., Tims, M., \& Derks, D. (2012). Proactive personality and job performance: The role of job crafting and work engagement. Human Relations, 65(10) 1359-1378. https://doi.org/10.1177/0018726712453471

Bangdiwala, S.I. (2016). Understanding significance and $p$-values. Nepal Journal of Epidemiology, 6(1), 522. https://doi.org/10.3126/nje.v6i1.14732

Berg, J.M., Dutton, J.E., \& Wrzesniewski, A. (2013). Job crafting and meaningful work. In B.J. Dik, Z.S. Byrne, \& M.F. Steger (Eds.), Purpose and meaning in the workplace (pp. 81-104). American Psychological Association. https://doi. org/10.1037/14183-005

Berg, J.M., Grant, A.M., \& Johnson, V. (2010). When callings are calling: Crafting work and leisure in pursuit of unanswered occupational callings. Organization Science, 21(5), 973-994. https://doi.org/10.1287/orsc.1090.0497

Bindl, U.K., \& Parker, S.K. (2012). Affect and employee proactivity: A goal-regulatory perspective. In N. Ashkanasy, C. Härtel, W. Zerbe (Eds.), Research on emotion in organizations (vol. 8, pp. 225-254). Bingley, UK: Emerald.

Bollen, K.A. (1989). Structural equations with latent variables. New York, NY: Wiley.

Boyd, S.B. (2007). Social exchange and conflict management tactic selection among police officers. Doctoral dissertation, Lubbock, TX: Texas University.

Brackett, M.A., Rivers, S.E., Shiffman, S., Lerner, N., \& Salovey, P. (2006). Relating emotional abilities to social functioning: A comparison of self-report and performance measures of emotional intelligence. Journal of Personality and Social Psychology, 91(4), 780.

Brotheridge, C.M., \& Grandey, A.A. (2002). Emotional labor and burnout: Comparing two perspectives of 'people work'. Journal of Vocational Behavior, 60(1), 17-39.

Brunetto, Y., Teo, S.T., Shacklock, K., \& Farr-Wharton, R. (2012). Emotional intelligence, job satisfaction, well-being and engagement: Explaining organisational commitment and turnover intentions in policing. Human Resource Management Journal, 22(4), 428-441. https://doi.org/10.1111/j.1748-8583.2012.00198.x

Caldwell, D.F., \& O'Reilly, C.A. (2003). The determinants of team-based innovation in organizations. The role of social influence. Small Group Research, 34(4), 497-517. https://doi.org/10.1177/1046496403254395

Caruso, D.R., \& Salovey, P. (2004). The emotionally intelligent manager. San Francisco, CA: Jossey-Bass.

Cohen, J., Cohen, P., West, S.G., \& Aiken, L.S. (2003). Applied multiple regression/ correlation analysis for the behavioural sciences (3rd edn.). Mahwah, NJ: Lawrence Erlbaum.
Combrink, J.H. (2014). The cost of workplace conflict at company $A$ and company B's shared premises. Doctoral dissertation. Bloemontein: University of the Free State.

Côté, S., Kraus, M.W., Cheng, B.H., Oveis, C., Van der Löwe, I., Lian, H., \& Keltner, D. (2011). Social power facilitates the effect of prosocial orientation on empathic accuracy. Journal of Personality and Social Psychology, 101(2), 217. https://doi. org/10.1037/a0023171

De Bruin, G.P., \& Taylor, N. (2006). The job demands-control model of job strain across gender. SA Journal of Industrial Psychology, 32(1), 66-73. https://doi.org/10.4102/ sajip.v32i1.227

De Dreu, C.K.W., \& Weingart, L.R. (2003). Task versus relationship conflict, team performance and team member satisfaction: A meta-analysis. Journal of Applied Psychology, 88(4), 741-749. https://doi.org/10.1037/0021-9010.88.4.741

Demerouti, E. (2014). Design your own job through job crafting. European Psychologist, 19(4), 237-247. https://doi.org/10.1027/1016-9040/a000188

Desivilya, H.S., Somech, A., \& Lidgoster, H. (2010). Innovation and conflict management in work teams: The effects of team identification and task and relationship conflict. Negotiation and Conflict Management Research, 3(1), 28-48. https://doi org/10.1111/j.1750-4716.2009.00048.x

Devonish, D., \& Greenidge, D. (2010). The effect of organizational justice on contextual performance, counterproductive work behaviours, and task performance: Investigating the moderating role of ability-based emotional intelligence. International Journal of Selection and Assessment, 18(1), 75-86. https://doi. org/10.1111/j.1468-2389.2010.00490.x

De Wit, F.R., Greer, L.L., \& Jehn, K.A. (2012). The paradox of intragroup conflict: A meta-analysis. Journal of Applied Psychology, 97(2), 360. https://doi.org/10.1037/ a0024844

Dunfield, K.A. (2014). A construct divided: Prosocial behavior as helping, sharing, and comforting subtypes. Frontiers in Psychology, 5, 958. https://doi.org/10.3389/ fpsyg.2014.00958

Elfenbein, H.A. (2016). Emotional division-of-labor: A theoretical account. Research in Organizational Behavior, 36, 1-26. https://doi.org/10.1016/j.riob.2016.11.001

Erkutlu, H., \& Chafra, J. (2012). The impact of team empowerment on proactivity: The moderating roles of leaders' emotional intelligence and proactive personality. Journal of Health Organization and Management, 26(5), 560-577. https://doi. Journal of Health Organization and
org/10.1108/14777261211256918

Eslami, A., \& Arshadi, N. (2016). Effect of organizational competitive climate on organizational prosocial behavior: Workplace envy as a mediator. Age, 24(30), 49.

Finkelstein, M.A. (2011). Intrinsic and extrinsic motivation and organizational citizenship behavior: A functional approach to organizational citizenship behavior. Journal of Psychological Issues in Organizational Culture, 2(1), 19-34. https://doi. org/10.1002/jpoc.20054

Fredrickson, B.L. (2001). The role of positive emotions in positive psychology: The broaden-and-build theory of positive emotions. American Psychologist, 56(3), 218. https://doi.org/10.1037/0003-066X.56.3.218

Frese, M., \& Fay, D. (2001). Personal initiative: An active performance concept for work in the 21st century. Research in Organizational Behavior, 23, 133-187. https://doi.org/10.1016/S0191-3085(01)23005-6

Gardner, W.L., Pickett, C.L., \& Brewer, M.B. (2000). Social exclusion and selective memory: How the need to belong influences memory for social events. Personality and Socia Psychology Bulletin, 26(4), 486-496. https://doi.org/10.1177/0146167200266007

Ghitulescu, B.E. (2007). Shaping tasks and relationships at work: Examining the antecedents and consequences of employee job crafting. Doctoral dissertation. Pittsburgh, PA: University of Pittsburgh.

Gilson, L.L., \& Shalley, C.E. (2004). A little creativity goes a long way: An examination of teams' engagement in creative processes. Journal of Management, 30(4), 453-470. https://doi.org/10.1016/j.jm.2003.07.001

Goodman, S.A., \& Svyantek, D. J. (1999). Person-organization fit and contextual performance: Do shared values matter? Journal of Vocational Behaviour, 55(2) 254-275. https://doi.org/10.1006/jvbe.1998.1682

Grant, A.M., \& Ashford, S.J. (2008). The dynamics of proactivity at work. Research in Organizational Behaviour, 28, 3-34. https://doi.org/10.1016/j.riob.2008.04.002

Greer, L.L., Jehn, K.A., \& Mannix, E.A. (2008). Conflict transformation: A longitudina investigation of the relationships between different types of intragroup conflict and the moderating role of conflict resolution. Small Group Research, 39(3), 278-302. https://doi.org/10.1177/1046496408317793

Hahn, S.E. (2000). The effects of locus of control on daily exposure, coping and reactivity to work interpersonal stressors: A diary study. Personality and Individual Differences, 29(4), 729-748. https://doi.org/10.1016/S0191-8869(99)00228-7

Hakanen, J.J., Perhoniemi, R., \& Toppinen-Tanner, S. (2008). Positive gain spirals at work: From job resources to work engagement, personal initiative and work-unit innovativeness. Journal of Vocational Behaviour, 73, 78-91. https://doi. org/10.1016/j.jvb.2008.01.003

Hansen, R. (2015). The relationship between task conflict, task performance and team member satisfaction: The mediating role of relationship conflict. Master's thesis. Oslo: University of Oslo.

Hayes, A.F. (2013). Methodology in the social sciences. Introduction to mediation, moderation, and conditional process analysis: A regression-based approach. NY New York: Guilford Press.

Hayes, A.F. (2015). An index and test of linear moderated mediation. Multivariate Behavioral Research, 50(1), 1-22. https://doi.org/10.1080/00273171.2014.962683

Jackson, L. (2014). The work engagement and job performance relationship: Exploring the mediating effect of trait emotional intelligence. Master's thesis. San José, CA: San José State University. 
Jehn, K.A. (1995). A multimethod examination of the benefits and detriments of intragroup conflict. Administrative Science quarterly, 40(2), 256-282. https://doi. intragroup conflict. Adming
org/10.2307/2393638

Jehn, K.A., \& Chatman, J.A. (2000). The influence of proportional and perceptual conflict composition on team performance. International Journal of Conflict Management, 11(1), 56-73. https://doi.org/10.1108/eb022835

Jehn, K.A., \& Mannix, E.A. (2001). The dynamic nature of conflict: A longitudinal study of intragroup conflict and group performance. Academy of Management Journal, 44(2), 238-251. https://doi.org/10.2307/3069453

Joseph, D.L., \& Newman, D.A. (2010). Emotional intelligence: An integrative metaanalysis and cascading model. Journal of Applied Psychology, 95(1), 54. https:// doi.org/10.1037/a0017286

Kahya, E. (2007). The effects of job characteristics and working conditions on job performance. International Journal of Industrial Ergonomics, 37(6), 515-523. herformance. International Journal of Industric

Karasek, Jr. R.A. (1979). Job demands, job decision latitude, and mental strain: Implications for job redesign. Administrative Science Quarterly, 24(2), 285-308. https://doi.org/10.2307/2392498

Kraemer, H., Kiernan, M., Essex, M., \& Kupfer, D.J. (2008). How and why criteria defining moderators and mediators differ between the Baron \& Kenny and MacArthur approaches. Health Psychology, 27(2S), S101. https://doi. org/10.1037/0278-6133.27.2(Suppl.).S101

Liu, Y., Prati, L.M., Perrewe, P.L., \& Ferris, G.R. (2008). The relationship between emotional resources and emotional labor: An exploratory study. Journal of Applied Social Psychology, 38(10), 2410-2439. https://doi.org/10.1111/ j.1559-1816.2008.00398.x

Lopes, P.N., Grewal, D., Kadis, J., Gall, M., \& Salovey, P. (2006). Evidence that emotional intelligence is related to job performance and affect and attitudes at work. Psicothema, 18, 132-138.

Lukasik, M.A. (2009). The association between task conflict, relationship conflict, and peer performance appraisals. Unpublished dissertation, Chicago, IL: DePau University.

Madlock, P.E., \& Booth-Butterfield, M. (2012). The influence of relational maintenance strategies among co-workers. The Journal of Business Communication, 49(1), 21-47. https://doi.org/10.1177/0021943611425237

Matthews, G., Roberts, R.D., \& Zeidner, M. (2004). Target articles: Seven myths about emotional intelligence. Psychological Inquiry, 15(3), 179-196. https://doi. emotional intelligence. Psychological
org/10.1207/s15327965pli1503 01

Morrison, J. (2008). The relationship between emotional intelligence competencies and preferred conflict-handling styles. Journal of Nursing Management, 16(8), 974-983. https://doi.org/10.1111/j.1365-2834.2008.00876.x

Myers, S.A., \& Johnson, A.D. (2004). Perceived solidarity, self-disclosure, and trust in organizational peer relationships. Communication Research Reports, 21(1), 75-83. https://doi.org/10.1080/08824090409359969

Nielsen, K., \& Abildgaard, J.S. (2012). The development and validation of a job crafting measure for use with blue-collar workers. Work \& Stress, 26(4), 365-384. https:// doi.org/10.1080/02678373.2012.733543

Niessen, C., Weseler, D., \& Kostova, P. (2016). When and why do individuals craft their jobs? The role of individual motivation and work characteristics for job crafting. Human Relations, 69(6), 1287-1313. https://doi.org/10.1177/0018726715610642

O’Boyle, Jr. E.H., Humphrey, R.H., Pollack, J.M., Hawver, T.H., \& Story, P.A. (2011). The relation between emotional intelligence and job performance: A meta-analysis. Journal of Organizational Behavior, 32(5), 788-818. https://doi.org/10.1002/ job.714

Pallant, J. (2011). Survival manual. A step by step guide to data analysis using SPSS (4th edn.). Berkshire: Allen \& Unwin.

Pekaar, K.A., Bakker, A.B., Born, M.P., \& Van der Linden, D. (2018a). The consequences of self-and other-focused emotional intelligence: Not all sunshine and roses. Journal of Occupational Health Psychology, 24(4), 450-466. https://doi. Journal of Occupational
org/10.1037/ocp0000134

Pekaar, K.A., Bakker, A.B., Van der Linden, D., \& Born, M.P. (2018b). Self- and otherfocused emotional intelligence: Development and validation of the Rotterdam emotional intelligence scale (REIS). Personality and Individual Differences, 120 222-233. https://doi.org/10.1016/j.paid.2017.08.045

Pekaar, K.A., Van der Linden, D., Bakker, A.B., \& Born, M.P. (2020). Dynamic self- and other-focused emotional intelligence: A theoretical framework and research agenda. Journal of Research in Personality, 86, 1-11. https://doi.org/10.1016/j. jrp.2020.103958

Pelled, L.H., Eisenhardt, K.M., \& Xin, K.R. (1999). Exploring the black box: An analysis of work group diversity, conflict and performance. Administrative Science Quarterly, 44(1), 1-28. https://doi.org/10.2307/2667029

Petrides, K.V., \& Furnham, A. (2003). Trait emotional intelligence: Behavioura validation in two studies of emotion recognition and reactivity to mood induction. European Journal of Personality, 17(1), 39-57. https://doi.org/10.1002/per.466

Petrou, P., Demerouti, E., \& Schaufeli, W.B. (2015). Job crafting in changing organizations: Antecedents and implications for exhaustion and performance. Journal of Occupational Health Psychology, 20(4), 470. https://doi.org/10.1037/a0039003

Petrou, P., Demerouti, E., Peeters, M.C.W., Schaufeli, W.B., \& Hetland, J. (2012) Crafting a job on a daily basis: Contextual correlates and the link to work engagement. Journal of Organizational Behavior, 33(8), 1120-1141. https://doi. org/10.1002/job.1783

Podsakoff, P.M., MacKenzie, S.B., Paine, J.B., \& Bachrach, D.G. (2000). Organizational citizenship behaviors: A critical review of the theoretical and empirical literature and suggestions for future research. Journal of Management, 26(3), 513-563. https://doi.org/10.1177/014920630002600307
Prati, L., Douglas, C., Ferris, G., Ammeter, A., \& Buckley, M. (2003). Emotional intelligence, leadership effectiveness and team outcomes. The International Journal of Organizational Analysis, 11(1), 21-40. https://doi.org/10.1108/eb028961

Preacher, K.J., Rucker, D.D., \& Hayes, A.F. (2007). Addressing moderated mediation hypotheses: Theory, methods, and prescriptions. Multivariate Behavioural hesearch, 42(1), 185-227. https://doi.org/10.1080/00273170701341316
Ret

Promís, P. (2008). Are employers asking for the right competencies? A case for emotional intelligence. Library Leadership \& Management, 22(1), 24-30.

Rispens, S., \& Demerouti, E. (2016). Conflict at work, negative emotions, and performance: A diary study. Negotiation and Conflict Management Research, 9(2), 103-119. https://doi.org/10.1111/ncmr.12069

Rudolph, C.W., Katz, I.M., Lavigne, K.N., \& Zacher, H. (2017). Job crafting: A metaanalysis of relationships with individual differences, job characteristics, and work outcomes. Journal of Vocational Behavior, 102, 112-138. https://doi. org/10.1016/j.jvb.2017.05.008

Salanova, M., Peiró, J.M., \& Schaufeli, W.B. (2002). Self-efficacy specificity and burnout among information technology workers: An extension of the job demand-control model. European Journal of Work and Organizational demachology, 11(1), 1-25.
Psy

Salovey, P., \& Mayer, J.D. (1990). Emotional intelligence. Imagination, Cognition and Personality, 9, 185-211. https://doi.org/10.2190/DUGG-P24E-52WK-6CDG

Schulz-Hardt, S., Jochims, M., \& Frey, D. (2002). Productive conflict in group decision making: Genuine and contrived dissent as strategies to counteract biased information seeking. Organizational Behavior and Human Decision Processes, 88(2), 563-586. https://doi.org/10.1016/S0749-5978(02)00001-8

Schutte, N.S., Malouff, J.M., Bobik, C., Coston, T.D., Greeson, C., Jedlicka, C., \& Wendorf, G. (2001). Emotional intelligence and interpersonal relations. The Journal of Social Psychology, 141(4), 523-536. https://doi.org/10.1080/ 00224540109600569

Schreurs, B.H., Hetty van Emmerik, I.J., Guenter, H., \& Germeys, F. (2012). A weekly diary study on the buffering role of social support in the relationship between job insecurity and employee performance. Human Resource Management, 51(2), 259-279.

Simons, T.L., \& Peterson, R.S. (2000). Task conflict and relationship conflict in top management teams: The pivotal role of intragroup trust. Journal of Applied Psychology, 85(1), 102. https://doi.org/10.1037/0021-9010.85.1.102

Slemp, G.R., \& Vella-Brodrick, D.A. (2013). The job crafting questionnaire: A new scale to measure the extent to which employees engage in job crafting. International Journal of Wellbeing, 3(2), 126-146.

Slemp, G.R., Kern, M.L., \& Vella-Brodrick, D.A. (2015). Workplace well-being: The role of job crafting and autonomy support. Psychology of Well-being, 5(1), 7. https:// doi.org/10.1186/s13612-015-0034-y

Sparrowe, R.T., Liden, R.C., Wayne, S.J., \& Kraimer, M.L. (2001). Social networks and the performance of individuals and groups. Academy of Management Journal, 44(2), 316-325. https://doi.org/10.5465/3069458

Spreitzer, G.M., \& Sonenshein, S. (2003). Positive deviance and extraordinary organizing. Positive Organizational Scholarship, 207, 224.

SPSS Inc. (2018). IBM SPSS Statistics for Windows, Version 25.0. Armonk, NY: IBM Corp.

Theorell, T., \& Karasek, R.A. (1996). Current issues relating to psychosocial job strain and cardiovascular disease research. Journal of Occupational Health Psychology, 1(1), 9. https://doi.org/10.1037/1076-8998.1.1.9

Theorell, T., Karasek, R.A., \& Eneroth, P. (1990). Job strain variations in relation to plasma testosterone fluctuations in working men - a longitudinal study. Journal of internal medicine, 227(1), 31-36. https://doi.org/10.1111/j.1365-2796.1990. tb00115.x

Thompson, J.A. (2005). Proactive personality and job performance: A social capital perspective. Journal of Applied Psychology, 90(5), 1011-1017. https://doi. org/10.1037/0021-9010.90.5.1011

Tims, M., \& Bakker, A.B. (2010). Job crafting: Towards a new model of individual job redesign. SA Journal of Industrial Psychology, 36(2), 1-9. https://doi.org/10.4102/ sajip.v36i2.841

Tims, M., Bakker, A.B., \& Derks, D. (2012). The development and validation of the job crafting scale. Journal of Vocational Behavior, 80(1), 173-186. https://doi. org/10.1016/j.jvb.2011.05.009

Tims, M., Bakker, A.B., \& Derks, D. (2013). The impact of job crafting on job demands, job resources, and well-being. Journal of Occupational Health Psychology, 18(2), 230-240. https://doi.org/10.1037/a0032141

Tims, M., Bakker, A.B., \& Derks, D. (2015). Job crafting and job performance: A longitudinal study. European Journal of Work and Organizational Psychology, 24(6), 914-928. https://doi.org/10.1080/1359432X.2014.969245

Tornau, K., \& Frese, M. (2013). Construct clean-up in proactivity research: A metaanalysis on the nomological net of work-related proactivity concepts and their incremental validities. Applied Psychology: An International Review, 62, 44-96. incremental validities. Applied Psychology: An Internc
https://doi.org/10.1111/j.1464-0597.2012.00514.x

Trougakos, J.P., Beal, D.J., Green, S.G., \& Weiss, H.M. (2008). Making the break count: An episodic examination of recovery activities, emotional experiences, and positive affective displays. Academy of Management Journal, 51(1), 131-146. https://doi.org/10.5465/amj.2008.30764063

Tsai, W.C., Chen, C.C., \& Liu, H.L. (2007). Test of a model linking employee positive moods and task performance. Journal of Applied Psychology, 92(6), 1570. https:// doi.org/10.1037/0021-9010.92.6.1570 
Van Rooy, D., \& Viswesvaran, C. (2004). Emotional intelligence: A meta-analytic investigation of predictive validity and nomological net. Journal of Vocational Behavior, 65(1), 71-95. https://doi.org/10.1016/S0001-8791(03)00076-9

Waldman, D.A. (1994). The contributions of total quality management to a theory of work performance. Academy of Management Review, 19(3), 510-536. https:// doi.org/10.5465/amr.1994.9412271811

Wall, T.D., Jackson, P.R., Mullarkey, S., \& Parker, S.K. (1996). The demands-contro model of job strain: A more specific test. Journal of Occupational and Organizational Psychology, 69(2), 153-166.

Warren, D.E. (2003). Constructive and destructive deviance in organizations. Academy of management Review, 28(4), 622-632.

Welbourne, T.M., Johnson, D.E., \& Erez, A. (1998). The role-based performance scale: Validity analysis of a theory-based measure. Academy of Management Journal, 41(5), 540-555. https://doi.org/10.5465/256941

Werner, E.E. (2000). Protective factors and individual resilience. Handbook of Early Childhood Intervention, 2, 115-132.
Williams, L.J., \& Anderson, S.E. (1991). Job satisfaction and organizational commitment as predictors of organizational citizenship and in-role behaviours. Journal of Management, 17(3), 601-617. https://doi.org/10.1177/014920639101700305

Worline, M.C., Wrzesniewski, A., \& Rafaeli, A. (2002). Courage and work: Breaking routines to improve performance. In R. Lord, R. Klimoski, \& role of emotions in organizational behavior (pp. 295-330). San Francisco, CA: role of emotior Jossey-Bass.

Wrzesniewski, A., \& Dutton, J.E. (2001). Crafting a job: Revisioning employees as active crafters of their work. Academy of Management Review, 26(2), 179-201. active crafters of their work. Acade

Yang, J., \& Mossholder, K.W. (2004). Decoupling task and relationship conflict: The role of intragroup emotional processing. Journal of Organizational Behavior: role of intrageup enotion: Psychology and Behavior, 25(5), 589-605.

Yukl, G. (2002). Leadership in organizations (5th edn.). Upper Saddle River, NJ: Prentice Hall. 